$\left.\begin{array}{l}\text { Our Nature } \\ \text { Journal homepage: http://nepjol.info/index.php/ON }\end{array}\right)$

\title{
Effect of legume and grazing intensity on soil organic carbon and total nitrogen stock in Himalayan rangeland
}

\author{
Dil Kumar Limbu ${ }^{1 *}$ Madan Koirala ${ }^{2}$ and Zhanhuan Shang ${ }^{3}$ \\ ${ }^{I}$ Central Campus of Technology, Dharan, Tribhuvan University, Nepal \\ ${ }^{2}$ Central Department of Environmental Science, Kirtipur, Tribhuvan University, Nepal \\ ${ }^{3}$ School of Life Science, Lanzhou University, China \\ *email:dilklimbu@gmail.com
}

\begin{abstract}
Organic carbon and total nitrogen are important components of global carbon and nitrogen cycle in rangeland ecology.Objective of this study is to identify and quantify the present status of carbon and nitrogen pool in Himalayan rangeland and to make recommendations for enhancing carbon and nitrogen storage for rangeland management. To meet the aforementioned objectives, the field study was conducted in 2011 -2013. The study showed that soil organic carbon was highest in legume seeding sub-plot in top soil $(28.53 \pm 2.6)$ t/ha of heavily grazed area. Similarly, total nitrogen was highest in bottom soil $(2.81 \pm 0.16)$ t/ha in legume seeding sub-plot of enclosed ungrazed area. Usually, heavily grazed and legume seeding sub-plots had more soil organic carbon and total nitrogen concentration compared to others. The value of above ground biomass was in increasing trend with decreasing grazing intensity but for below ground biomass, it was just the reverse. On the basis of the results of this study, the grazing intensity is positively correlated with above ground and below ground biomass and soil organic carbon but no correlation with soil total nitrogen and soil bulk density. Key words: Biomass, Carbon, Climate change, Himalayan, Soil, Rangeland.
\end{abstract}

\footnotetext{
DOI: https://doi.org/10.3126/on.v17i1.33981

Manuscript details: Received: 03.10.2019/ Accepted: 15.11.2019

Citation: Limbu, D.K., M. Koirala and Z. Shang 2019. Effect of legume and grazing intensity on soil organic carbon and total nitrogen stock in Himalayan rangeland. Our Nature 17 (1): 1-8. DOI: https://doi.org/10.3126/on.v17i1.33981

Copyright: Limbu, Koirala and Shang 2019. Creative Commons Attribution - Non Commercial 4.0 International License.
}

\section{Introduction}

Rangelands occupy approximately 40-70\% globally (Branson et al., 1981; Havstad et al., 2009; Wang and Fang, 2009) of the terrestrial land surface. In Nepal, the rangeland occupies 23\% of total land (GoN, 2012). Rangeland contains about $36 \%$ of the world's total carbon in aboveand below-ground biomass (Solomon et al., 1993). It is estimated that rangelands globally sequester carbon (C) in soil at a rate of $0.5 \mathrm{Pg}$ C/yr (Schlesinger, 1977 and Scurlock and Hall et al., 1998). Some studies indicate that rangeland management practices could provide a substantial global sink for atmospheric carbon in grasslands. Grazing can increase, decrease, or maintain unaltered the size of both pools (Milchunas and Lauenroth, 1993; Derner and Schuman, 2007; Pineiro et al., 2009). High altitude and cold rangeland have high capacity to sink carbon on soil. The soil organic carbon pool is important and at risk especially in the Himalayan region (Bhattacharya et al., 2000). Despite having high carbon stocking capacity rangelands have poor carbon stock. The rangeland productivity and carbon pool are declining day by day due to highly degradation and excess exploitation. Various management practices on rangelands have not been observed and recommended for carbon stocking in nature yet. Thus it is essential to find the actual carbon stocking rate of the rangeland. The objective of the present study was to estimate total carbon on various management practices in Himalayan rangeland. Grazing experiment was conducted in a temperate grassland of Eastern Nepal to (1) 


\section{Our Nature | December 2019 | 17 (1): 1-8}

evaluate the influence of different grazing intensities on soil organic carbon (SOC) and total nitrogen (TN) storage, (2) explore the influence of legume treatment on the distribution of SOC and TN in soil profiles and (3) relate the soil bulk density and nitrogen on $\mathrm{C}$ distribution (4) test the hypothesis that grazing intensity and legume treatment alter the SOC and TN stock in Himalayan rangeland.

\section{Materials and methods \\ Study area}

The study was conducted in the Tinjure-MilkeJaljale (TMJ) Mountain ridge, political border of three districts, i.e., Taplejung, Tehrathum and Sankhuwasabha of Eastern Nepal. Geographically the area lies between $27^{0} 6^{\prime} 57^{\prime \prime}$ to $27^{0} 30^{\prime} 8^{\prime \prime}$ north latitude and $87^{\circ} 19^{\prime} 46^{\prime \prime}$ to $87^{\circ} 38^{\prime} 14^{\prime \prime}$ east longitude (Fig. 1). The climate of the study area is moist temperate type, which receives moderate snowfall from December to February. Average climatic detail (2011-2013) of the study area is given in Fig. 2. Mean annual maximum temperature was $23.65 \pm 4.95^{\circ} \mathrm{C}$, whereas mean annual minimum temperature was $4.12 \pm 5.24^{\circ} \mathrm{C}$. Mean annual rainfall was 2,274 $\mathrm{mm}$.
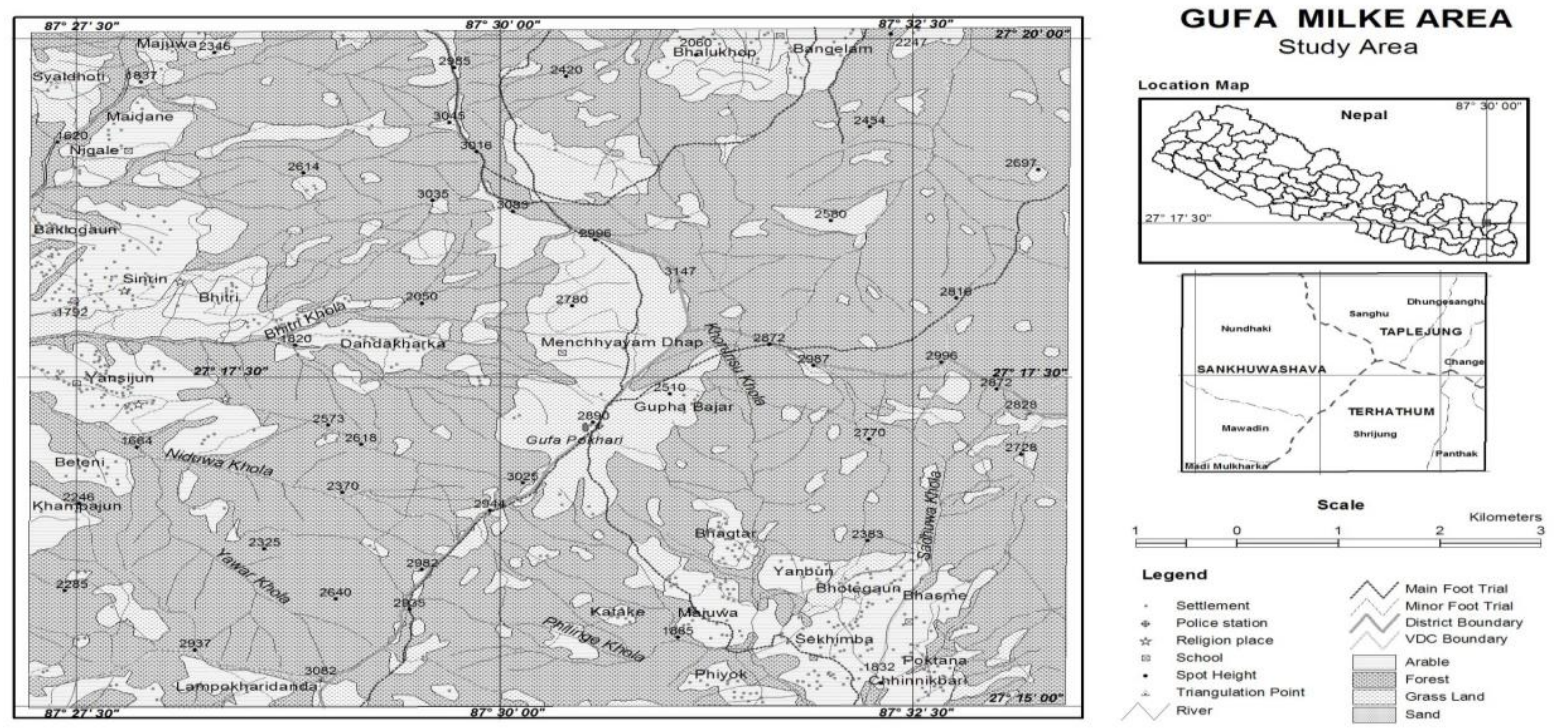

Figure 1. Map of the Tinjure MilkeJaljale (TMJ) study area, Gufa-Milke (GM)

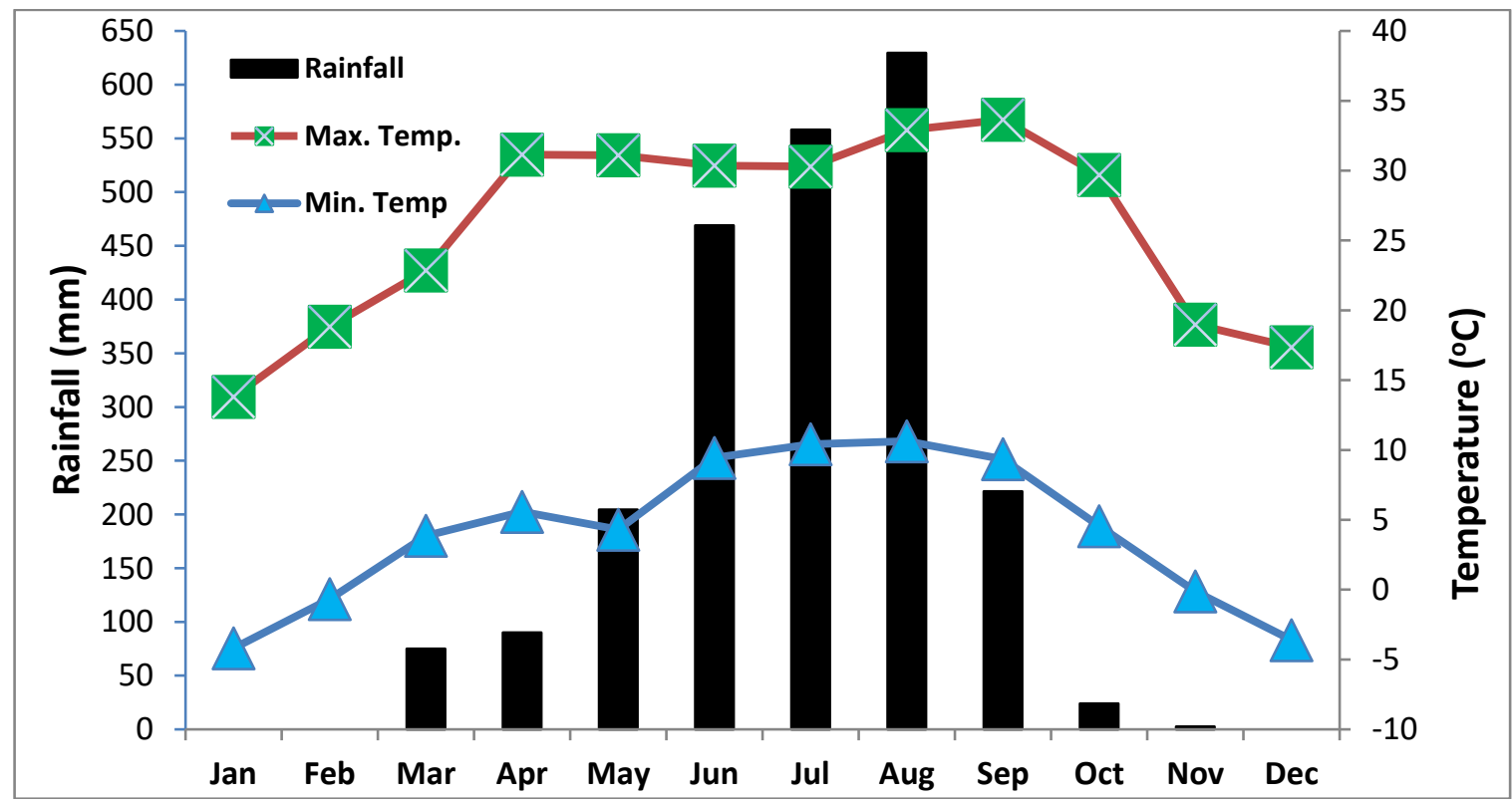

Figure 2. Climatic detail of the study area (2011-2013) Source: Field study, 2013 


\section{Our Nature | December 2019 | 17 (1): 1-8}

The study area was established in 2011 in a randomized block design. Three experimental plots were fixed, viz., (a) rangeland with heavily grazed (heavily season-long grazing) HG (b) rangeland with occasional grazed, SG (c) ungrazed enclosures rangeland, UG. Continuous heavily season long grazing means the rangeland is grazed as usual way as it runs since its practices without disturbing. Each plot was further divided into legume seeding sub-plot and non-legume sub-plot. Ten sampling points were established in two parallel transect lines at each sub-plot. One quadrat $(30 \mathrm{~cm} \times 30 \mathrm{~cm})$ was established at each sampling point.

\section{Soil sampling}

Soil samples were collected from each sampling point with the help of soil core having $4 \mathrm{~cm}$

$$
\text { Bulk Density }\left(\mathrm{g} / \mathrm{cm}^{3}\right)=\frac{\text { Oven Dry Mass }(\mathrm{g})}{\text { Core Volume }\left(\mathrm{cm}^{3}\right)-\left[\frac{\text { Mass of Coarse fragments }(\mathrm{g})}{\text { Density of Rock fragments }\left(\mathrm{g} / \mathrm{cm}^{3}\right)}\right]} \ldots . . \mathrm{C} 1
$$

\section{Soil analysis}

Determination of soil bulk density

Bulk density of sampled soil was determined by standard method (Blake and Hartge, 1986). Equation (C1) was used for the calculation of soil bulk density.

diameter and $15 \mathrm{~cm}$ length. The $15 \mathrm{~cm}$ long soil $10-15 \mathrm{~cm}$ (third soil profile). The soil sample was dried in an oven at $100^{\circ} \mathrm{C}$ till constant weight. It was crumbled with thumbs and sieved through $2 \mathrm{~mm}$ sieve. Meanwhile, bulk density of soil sample was taken. The remaining particles were weighed, sieved and stored for further analyses.

\section{Determination of soil organic carbon (SOC)}

Soil organic carbon was analyzed from stored sample by the (Walkley and Black, 1934). Chromic Acid Wet Oxidation Method. The organic carbon (\%) and total organic carbon were calculated using the equations (C2) and (C3), respectively.
Where, $\mathrm{N}=$ normality of $\mathrm{K}_{2} \mathrm{Cr}_{2} \mathrm{O}_{7}, \mathrm{~T}=$ volume of $\mathrm{FeSO}_{4}$ used in the sample titration $(\mathrm{ml})$

$\mathrm{S}=$ volume of $\mathrm{FeSO}_{4}$ used in the blank titration $(\mathrm{ml})$, ODW $=$ oven-dry weight $(\mathrm{g})$ of soil sample

Soil Organic Carbon $(\mathrm{SOC})=$ organic carbon content $(\%)$ of soil $\times$ soil bulk density

$$
\left(\mathrm{g} / \mathrm{cm}^{3}\right) \times \text { thickness of horizon }(\mathrm{cm}) \text {. }
$$

\section{Determination of total nitrogen (TN)}

The nitrogen content in soil sample was determined by the Kjeldahl method (Pansu and Gautheyrou, 2006). The nitrogen $\%$ and total nitrogen were determined using the relation $\mathrm{N} 1$ and $\mathrm{N} 2$, respectively:

$$
\text { Nitrogen }(\%, \text { wet basis })=\frac{(\text { Sample titer }- \text { Blank titer }) \times \mathrm{N} \text { of } \mathrm{HCl} \times 14 \times 100 \times 100)}{\text { Aliquot }(\mathrm{ml}) \times \text { Wt. of sample }(\mathrm{g}) \times 1000}
$$

Total Nitrogen $(\mathrm{TN})=$ Organic Nitrogen content $(\%)$ of soil $\times$ soil bulk density $\left(\mathrm{g} / \mathrm{cm}^{3}\right)$

$$
\times \text { thickness of horizon }(\mathrm{cm})
$$

\section{Statistical analyses}

Data analyses were carried out by using IBMSPSS statistics version 20 (IBM, 2011) software. Three-way ANOVAs were used to analyze the main and interactive effects of grazing intensities, legume treatment and soil profiles on total nitrogen, soil organic carbon and ratio of carbon and nitrogen (C:N). Significance levels were set at $\alpha=0.05$ for all tests. Residuals were examined and data were transformed when necessary to improve homoscedasticity. Fisher's Least Significant Difference (LSD) was used to test the significance of means that were 
considered significantly different at $\alpha=0.05$ probability level.

\section{Results and discussion \\ Soil Organic Carbon (SOC) and Total Nitrogen (TN)}

This study revealed that soil organic carbon was highest in legume over-seeded plot in $0-5 \mathrm{~cm}$ depth $(28.53 \pm 2.6) \mathrm{t} / \mathrm{ha}$ of heavily grazed area and lowest in non-legume plot in $10-15 \mathrm{~cm}$ depth $(13.96 \pm 1.26) \mathrm{t} / \mathrm{ha}$ of occasionally grazed area. Usually, there were general decreasing trends for soil organic carbon concentration with increasing soil depth in both legume and nonlegume heavily grazed areas as well as occasionally grazed area but differences were not significant (Figs. $3 \mathrm{~A}$ and C). Conversely, SOC was more or less equal in all depth in enclosed un-grazed area (Fig. 1 A). Regardless of the legume treatment in study area, SOC concentration was not statistically significant among the grazing intensities plots. The main effect of grazing intensity on soil organic carbon was not significant but soil core depth and legume over-seeded $(\mathrm{F}=9.02, \mathrm{p}=0.000)(\mathrm{F}=$ Total nitrogen was highest in $10-15 \mathrm{~cm}$ depth $(2.81 \pm 0.16) \mathrm{t} / \mathrm{ha}$ in legume over-seeded plot and lowest in $5-10 \mathrm{~cm}$ depth $(0.89 \pm 0.04)$ t/ha in non-legume plot of enclosed un-grazed.
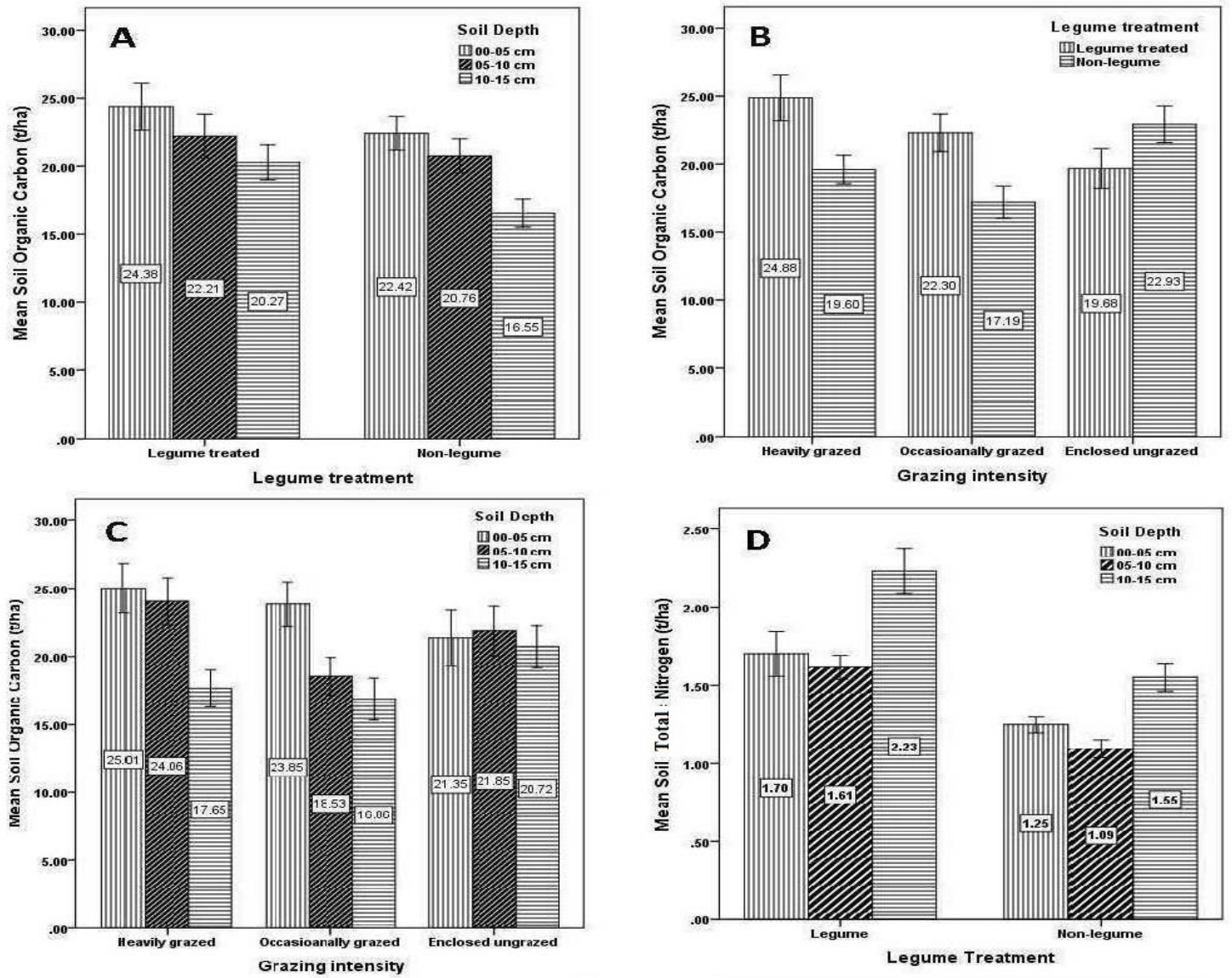

$6.03, \mathrm{p}=0.01$ ) were significant. Similarly, interaction effect of the independent variables of the research showed the following results. Heavily grazed and occasionally grazed area had significantly high SOC concentration in legume over-seeded plot than non-legume plot $(\mathrm{F}=9.91$, $\mathrm{p}=0.002$ and $\mathrm{F}=9.28, \mathrm{p}=0.003$, respectively) but un-grazed plot had marginal significantly heavily grazing area, $10-15 \mathrm{~cm}$ depth had significantly less SOC than $0-5 \mathrm{~cm}$ depth $(\mathrm{p}=$ $0.001)$ and $5-10 \mathrm{~cm}$ depth $(\mathrm{p}=0.003)$. In occasionally grazed area, $0-5 \mathrm{~cm}$ depth had significantly high $\mathrm{SOC}$ than $5-10 \mathrm{~cm}(\mathrm{p}=0.01)$ and $10-15 \mathrm{~cm}$ depth $(\mathrm{p}=0.001)$. On the contrary, soil depth had no effect in un-grazed plot. The interaction effect on soil organic carbon of legume treatment was significantly high in $0-5 \mathrm{~cm}$ than $10-15$ depth $(\mathrm{p}=0.01)$ and other depth comparisons were not significant. Similarly, non-legume plot, $10-15$ $\mathrm{cm}$ depth had significantly less SOC than $0-5$ $\mathrm{cm}$ depth and $5-10 \mathrm{~cm}$ depth $(\mathrm{p}=0.001$ and $\mathrm{p}=$

0.01 , respectively). less SOC $(F=3.75, p=0.05)$. Similarly, in 

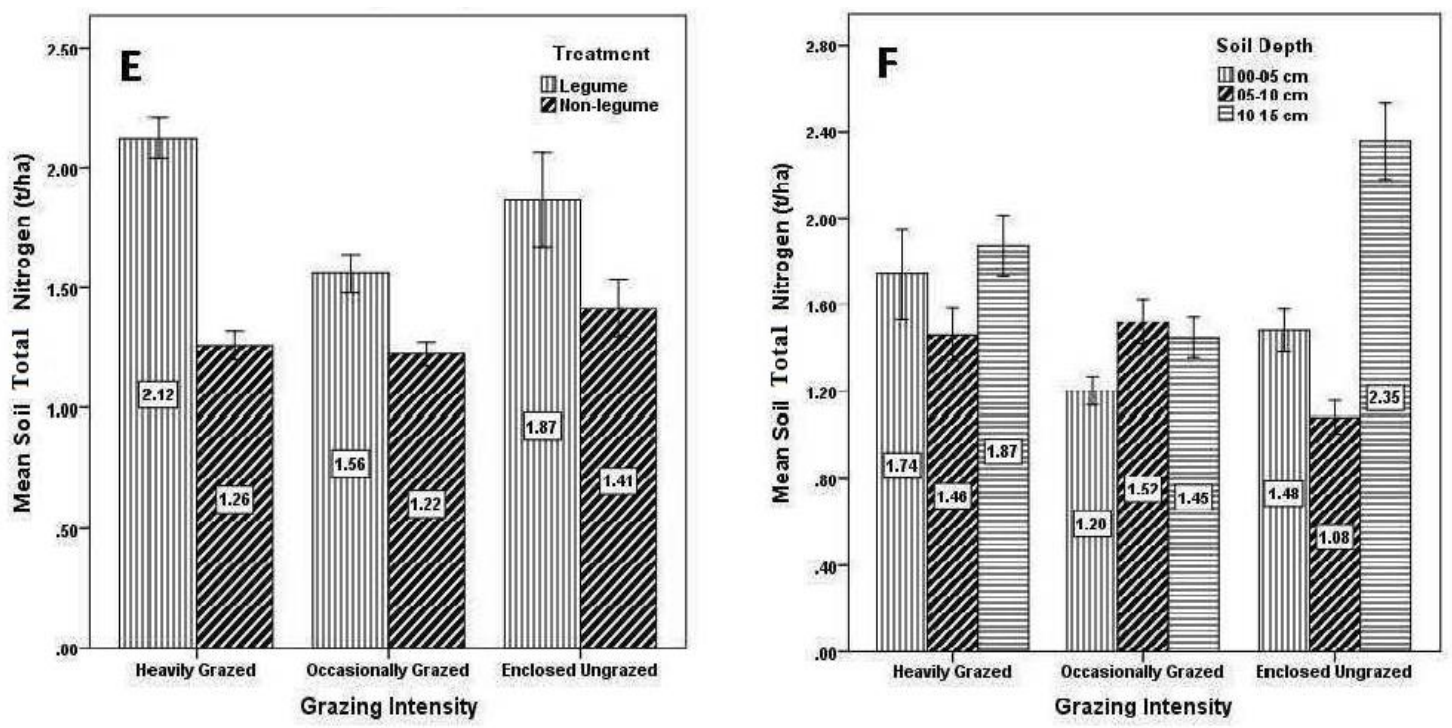

Figure 3. SOC and TN change on High altitude Himalaya rangeland under various managements $(A, D)$ interaction effects of soil depth and legume treatment on SOC and TN (B, E), interaction effects of grazing intensity and legume treatment on SOC and TN $(\mathrm{C}, \mathrm{F})$ interaction effects of grazing intensity and soil depth on SOC and TN.

Study revealed that total nitrogen concentration was higher in legume over-seeded plot than in non-legume plot in all grazing types (Fig. $3 \mathrm{E}$ and F). The difference was significant. On the other hand, there was inconsistent TN concentration in soil depth of various grazing intensity. However, their differences were significant (Fig. 3 D).

There was a significant main effect for grazing intensity $(\mathrm{F}=14.76, \mathrm{p}=0.000)$, legume treatment $(\mathrm{F}=129.87, \mathrm{p}=0.000)$ and soil depth $(\mathrm{F}=45.29, \mathrm{p}=0.000)$ on total nitrogen concentration. Grazing intensity and legume treatment had highly significant effect towards total nitrogen concentration. As can be seen interaction effect in Fig. 3, in the all grazing types had significantly high total nitrogen on legume overseeded plot than non-legume plot $(\mathrm{F}=106.656, \mathrm{p}$ $=0.000, \mathrm{~F}=16.14, \mathrm{p}=0.0001$ and $\mathrm{F}=29.08, \mathrm{p}$ $=0.000$, respectively). Similarly, the enclosed non-grazed plot had significantly high TN on 10$15 \mathrm{~cm}$ soil depth $(\mathrm{F}=80.44, \mathrm{p}=0.0000)$ than upper layers, $0-5 \mathrm{~cm}$ depth and $5-10 \mathrm{~cm}$ depth. The interaction of the legume treatment and soil depth on total nitrogen showed that all depth of soil, viz., 0-5 cm, 5-10 $\mathrm{cm}$ and $10-15 \mathrm{~cm}$ had significantly high TN in legume over-seeded plot than non-legume pots $(\mathrm{F}=29.32, \mathrm{p}=0.000,(\mathrm{~F}=$ $38.67, \mathrm{p}=0.000$ and $(\mathrm{F}=65.68, \mathrm{p}=0.000)$.

\section{Grazing and legume treatment on Soil $C$ and $N$ storage}

The results confirm that grazing impact is inconsistent on $\mathrm{C}$ and $\mathrm{N}$ storage while legume treatment shows positive correlation on carbon and nitrogen storage in high altitude rangeland. In the case of soil depth, $\mathrm{N}$ storage shows increasing trend along with soil depth but $\mathrm{C}$ storage shows decreasing order with soil depth in the Himalayan rangeland. Heavily trampling and wash out with rain water may cause instability of total nitrogen on surface soil. In the result, soil C and $\mathrm{N}$ storage were slightly lesser in occasionally grazed area compared to heavily grazed and enclosed ungrazed area (Fig. 3). In the finding, SOC concentration was not statistically significant among the various grazing intensities. Possible explanations for soil $\mathrm{C}$ storage enhancement with ungrazed exclosure include increases in production, elevated nutrient availabilities, and facilitation of vegetation regeneration (Frank and McNaughton, 1993; Milchunas and Lauenroth, 1993; Han et al., 2008). Some scholars suggested that grazing accelerates the rate of nutrient cycling by stimulating primary production and net nutrient flux, thereby increasing the percentage of the system's nutrients that are available and which cycle rapidly near the soil surface (Ruess and McNaughton, 1987). On the other hand, it is reported from temperate grassland of Northeast, India, maximum values of soil organic $\mathrm{C}$ and total $\mathrm{N}$ in the light grazing site may be due to the 


\section{Our Nature | December 2019 | 17 (1): 1-8}

presence of a large standing pool of organic matter and a higher rate of decomposition of plant litter through trampling by cattle (Devi et al., 2014). The low total soil organic $\mathrm{C}$ and $\mathrm{N}$ in the heavily grazing sites may be due to reduction in aboveground biomass owing to excessive grazing by the cattle. Similar findings were also reported in a sub-montane ecosystem (Bardgett et al., 2001) and in Inner Mongolian grassland (Gao et al., 2008). However, the legume treatment showed marginal significant difference for SOC on legume treated sub-plot and non-legume sub-plot of the study area (Fig. 3 A \& B). Some rangeland scholars reported that Carbon $(\mathrm{C})$ and Nitrogen $(\mathrm{N})$ storage declined in the heavily grazed grasslands, and soil acted as a $\mathrm{C}$ source. Declines in soil $\mathrm{C}$ and $\mathrm{N}$ storage under long-term heavy grazing have been reported (Cui et al., 2005; Elmore and Asner, 2006; Han et al., 2008 and Steffens et al., 2008). Repeated and frequent grazing results in decreased root elongation and biomass (Schuster, 1964 and Davidson, 1978), and hence lower $\mathrm{C}$ inputs into the soil from the roots (Holland and Detling 1990). Accumulation and storage of carbon and nitrogen on soil depend on the various conditions e. g. climate and biota (Jobbagy and Jackson, 2000), time (Vitousek and Reiners, 1975), topography, and parent material specifically soil texture; (Burke et al., 1989 and Torn et al., 1997). Thus, the magnitude of the carbon storage on rangeland depend not only grazing intensity but also other various conditions.

Research findings reveal those lower soil profiles $(10-15 \mathrm{~cm})$ of legume over-seeded plot as well as all grazing intensities have high TN concentration than surface soil profile. Soil depth is positively correlated to $\mathrm{TN}$ but negatively correlated to SOC concentration in Himalayan rangeland. The possible explanations are that the crude form of biomass contains more carbon at the surface layer because it is not buried while getting decomposed. Once buried, the biomass releases more nitrogen at depth. The higher levels of soil organic $\mathrm{C}$ and $\mathrm{N}$ in the surface soil of the grazed rangeland may be due in part to the effects of grazing on litter and standing dead components of the above-ground biomass. Although grass roots are the primary source of organic matter in rangeland soils, above-ground litter provides a secondary source (Aandahl, 1981). In contrary, reported that nitrogen storage was not significantly different in either the $0-10$ $\mathrm{cm}$ or $10-30 \mathrm{~cm}$ soil layers among various grazing intensities (He et al., 2011). Grazing increases SOC in deep soils but reduces it in shallow soils (Pineiro, 2009).

On the other hand, legumes are often preferentially grazed compared to grasses (Freer, 1981; Buxton et al., 1996; Dove, 1996 and Fales et al., 1996). Less organic material may be returned to soil for grazed legume mixed grassland as they are often used more efficiently than grasses for animal tissue gain (Varga et al., 1990 and Dove, 1996). Thus, C and N from legume mixed pastures were likely recycled through vegetation, cattle, and soil to a greater extent than $\mathrm{C}$ and $\mathrm{N}$ from without legume grassland.

\section{Conclusion}

The soil organic carbon and total nitrogen concentration were high in legume treated plot but did not significantly alter with grazing intensity. Soil organic carbon showed decreasing trend with increasing soil depth in legume and non-legume of heavily grazed areas as well as occasionally grazed area. This study concluded that short term grazing does not significantly alter the carbon and nitrogen but legume treatment increases both carbon and nitrogen because source of nitrogen accelerates the growth of herbs and add biomass and nutrients.

\section{Acknowledgements}

We would like to thank Mr. J. B. Limbu, Mr. M. Wongdi Sherpa and Mr. Pasang Sherpa who accompanied us for research work. Mr. Sherpa always inspired us to climb and stay at high altitude and very thankful for his accommodation management. One of the authors (D.K.) is grateful to the University Grants Commission, Nepal for the research fellowship.

\section{References}

Aandahl, A.R. 1981. Soils of the Great Plains: Land Use, Crops and Grasses. University of Nebraska Press, Nebraska.

Bardgett, R.D., A.C. Jones, D.L. Jones, S.J. Kemmitt and P.J. Hobbs 2001. Soil microbial community patterns related to the history and intensity of grazing in sub montane ecosystems. Soil Biology and Biochemistry 33: 1653-1664. http://dx.doi.org/10.1016/S0 038-0717(01)00086-4

Bhattacharya, T., D.K. Pal, C. Madal, and M. Velayuthum 2000. Organic carbon stock in Indian soil and their geographical distribution. Current Science 79: 655-660. 


\section{Our Nature | December 2019 | 17 (1): 1-8}

Blake, G.R. and K.H. Hartge 1986. Bulk Density. In A. Klute (Ed.), Methods of soil analysis. Part 1. (pp. 363-375). Madison, WI.: Am. Soc. Agron.

Branson, F.A., G.G. Gifford, K.G., Renard and R.F. Hadley 1981. Rangeland hydrology Dubuque, IA, USA: Kendall/Hunt Publishing Company, pp. 84.

Burke, I.C., C. Yonkers, W.J. Parton, C.V. Cole, K. Flach and D.S. Schimel 1989. Texture, climate, and cultivation effects on organic matter in Grassland Soils. Soil Science Society of America Journal 53(3): 800-805. http://dx.doi.org/10.2136/sssaj1989.036159 95005300030029x

Buxton, D.R., D.R. Mertens and D.S. Fisher 1996. Forage quality and ruminant utilization,. In L. E. Moser, D. R. Buxton and M. D. Casler (Eds.), Cool-Season Forage Grasses. Madison, WI: American Society of Agronomy, pp. 229-266.

Cui, X.Y., Y.F. Wang, H.S. Niu, J. Wu, S.P. Wang, E. Schnug and Y.H. Tang 2005. Effect of long-term grazing on soil organic carbon content in semiarid steppes in Inner Mongolia. Ecological Research 20: 519527. http://dx.doi.org/10.1007/s11284-0050063-8

Davidson, R.L. 1978. Root systems-the forgotten component of pastures. In J. R. Wiklson (Ed.), Plant relations in pastures. East Melbourne, Australia.: CSIRO, pp. 86-94.

Derner, J.D. and G.E. Schuman 2007. Carbon sequestration and rangelands: a synthesis of land management and precipitation effects. Journal of Soil and Water Conservation, 62(2): 77-85.

Devi, T.I., P.S. Yadava and S.C. Garkoti 2014. Cattle grazing influences soil microbial biomass in sub-tropical grassland ecosystems at Nambol, Manipur, northeast India. Tropical Ecology, 55(2): 195-206.

Dove, H. 1996. The ruminant, the rumen and the pasture resource: nutrient interactions in the grazing animal. In J. Hodgson and A. W. Illius (Eds.), The Ecology and Management of Grazing Systems. UK: CAB International. pp. $219-246$

Elmore, A. J. and G.P. Asner 2006. Effects of grazing intensity on soil carbon stocks following deforestation of a Hawaiian dry tropical forest. Global change biology, 12(9): 1761-1772.

Fales, S.L., A S. Laidlaw and M.G. Lambert 1996. Cool-season grass ecosystems. In L.
E. Moser, D. R. Buxton and M. D. Casler (Eds.), Cool-Season Forage Grasses. Madison, WI,: American Society of Agronomy.93). pp. 267-296. http://dx.doi.org/10. 2134/2009.grassland.c5

Frank, D.A. and S. J. McNaughton 1993. Evidence for the promotion of aboveground grassland production by native large herbivores in Yellowstone National Park. Oecologia, 96(2): 157-161. http://dx.doi. org/10.1007/BF00317727

Freer, M. 1981. The control of food intake by grazing animals. In F. H. W. Morley (Ed.), Grazing Animals World Animal Science Amsterdam: Elsevier, pp. 105-120.

Gao, Y., M. Giese, S. Lin, B. Sattelmacher and Y.B.H. Zhao 2008. Belowground net primary productivity and biomass allocations of a grassland in Inner Mongolia are affected by grazing intensity. Plant and Soil 307: 41-50. http://dx.doi.org/ 10.1007/s111 04-008-9579-3

GoN 2012. Rangeland policy. Live Stock Division, Kathmandu, Nepal

Han, G., X. Hao, M. Zhao, M. Wang, B.H. Ellert, W. Willms and M. Wang 2008. Effect of grazing intensity on carbon and nitrogen in soil and vegetation in a meadow steppe in Inner Mongolia. Agriculture, ecosystems and environment: 125(1), 21-32. http://dx. doi. org/10.1016/j.agee.2007. 11.009

Havstad, K.M., D.C. Peters, B. Allen-diaz, J. Bartolome, B.T. Bestelmeyer, D. Briske, ... J. Yao 2009. The western United States rangelands, a major resource. In W. F. Wedin and S. L. Fales (Eds.), Grassland quietness and strength for a new American agriculture. pp. 75

He, N.P., Y.H. Zhang, Q. Yu, Q.S. Chen, Q.M. Pan, G.M. Zhang and X.G. Han 2011. Grazing intensity impacts soil carbon and nitrogen storage of continental steppe. Ecosphere, 2(1): 1-10. http://dx.doi.org/ 10.1890/ES10-00017.1

Holland, E.A. and J.K. Detling 1990. Plant response to herbivory and belowground nitrogen cycling. Ecology, 71(3): 10401049. http://dx.doi.org/10.2307/1937372

IBM. 2011. IBM SPSS Statistics for Windows (Version 20.0). Armonk, NY: IBM Corp.

Jobbagy, E.G. and R.B. Jackson 2000. The vertical distribution of soil organic carbon and its relation to climate and vegetation. Ecological applications: 10(2): 423-436. 


\section{Our Nature | December 2019 | 17 (1): 1-8}

Milchunas, D.G. and W.K. Lauenroth 1993. Quantitative effects of grazing on vegetation and soils over a global range of environments. Ecological monographs, 63(4): 327366. http://dx.doi.org/ 10.2307/2937150

Pansu, M. and J. Gautheyrou 2006. Handbook of Soil Analysis Mineralogical, Organic and Inorganic Methods, Springer Berlin Heidelberg, New York

Pineiro, G., J.M. Paruelo, E.G. Jobbagy, R.D. Jackson, and M. Oesterheld 2009. Grazing effects on belowground $\mathrm{C}$ and $\mathrm{N}$ stocks along a network of cattle exclosures in temperate and subtropical grasslands of South America. Global Biogeochemical Cycles 23(2): 1-14.

Ruess, R.W. and S.J. McNaughton 1987. Grazing and the dynamics of miuient and energy regular. ed microbial processes in the Serengeti grasslands. Oikos 49: 101-110. http://dx.doi.org/10.2307/3565559

Schlesinger, W.H. 1977. Carbon balance in terrestrial detritus. Ann. Rev. Ecol. Syst. 8: 51-81. http://dx.doi.org/10.1146/annurev.es. 08.110177 .000411

Schuster, J.L. 1964. Root development of native plants under three grazing intensities. Ecology 45: 63-70. http://dx.doi.org/ 10.23 07/1937107

Scurlock, J.M.O. and D.O Hall 1998. The global carbon sink: a grassland perspective. Global Change Biology 4(2): 229-233. http://dx. doi. org/10.1046/j.1365-2486.1998. 00151.x

Solomon, A. M., I.C. Prentice, R. Leemans and W.P. Cramer 1993. The interaction of climate and land use in future terrestrial carbon storage and release. Water, Air, and Soil Pollution 70: 595-614. http://dx.doi. org/10.1007/BF01105024

Steffens, M., A. Kolbl, K.U. Totsche and I. Kogel-Knabner 2008. Grazing effects on soil chemical and physical properties in a semiarid steppe of Inner Mongolia (P.R. China) Geoderma 143: 63-72. http://dx.doi. org/10.1016/j.geoderma.2007.09.004

Torn, M.S., S.E. Trumbore,O.A. Chadwick, P.M. Vitousekand D.M. Hendricks 1997. Mineral control of soil organic carbon cycling. Nature 389: 170-173. http://dx.doi.org/10. $1038 / 38260$

Varga, G.A., H.F. Tyrrell, G.B. Huntington, D.R. Waldo and B.P. Glenn 1990. Utilization of nitrogen and energy by Holstein steers fed formaldehyde-and formic acid-treated alfalfa or orchardgrass silage at two intakes. Journal of animal science 68(11): 37803791 .

Vitousek, P.M. and W.A. Reiners 1975. Ecosystem Succession and Nutrient Retention: A Hypothesis. BioScience 25: 376-381. http://dx.doi.org/10.2307/1297148

Walkley, A. and I. A. Black 1934. An examination of Degtjareff method for determining soil organic matter and a proposed modification of the chromic acid titration method. Soil Science 27: 29-38. http://dx. doi.org/10.1097/00010694-193401000-0003

Wang, W. and J.Y. Fang 2009. Soil respiration and human effects on global grasslands. Global and Planetary Change 67: 2028.http://dx.doi.org/10.1016/j.gloplacha.200 8.12.011 